\title{
Enantioselective Rhodium-Catalyzed Addition of Potassium Alkenyltrifluoroborates to Cyclic Imines**
}

\author{
Yunfei Luo, Andrew J. Carnell, and Hon Wai Lam*
}

Chiral $\alpha$-branched allylic amines are important building blocks for organic synthesis, and several catalytic asymmetric methods have been developed for their synthesis. For example, enantioselective metal-catalyzed amination of allylic electrophiles ${ }^{[1,2,3]}$ and rearrangement of allylic imidates ${ }^{[4,5,6]}$ have proven to be highly effective.

An alternative approach to chiral allylic amines that can be advantageous from the viewpoint of convergency is the catalytic enantioselective union of an alkenyl nucleophile with an imine..$^{[7,8,9,10,11,12]}$ In view of the widespread success of enantioselective $\mathrm{Rh}(\mathrm{I})$-catalyzed additions of arylboron reagents to imines as a means to access chiral $\alpha$-aryl branched amines ${ }^{[13,14,15]}$ development of the corresponding reactions of alkenylboron reagents to prepare chiral $\alpha$-branched allylic amines should be an attractive goal. Surprisingly however, only very limited precedent exists for this transformation. ${ }^{[16]}$ Brak and Ellman have developed highly diastereoselective $\mathrm{Rh}$ (I)-catalyzed additions of alkenylboron reagents to $\mathrm{N}$-tertbutanesulfinyl aldimines (Scheme 1A). ${ }^{[17]}$ The only existing enantioselective variant is that of Shintani, Hayashi, and coworkers who, as part of a study involving additions of potassium aryltrifluoroborates to $N$-sulfonyl ketimines, also described one example using an alkenyltrifluoroborate (Scheme 1B) ${ }^{[15 c]}$ Also of relevance is a single example of an enantioselective $\mathrm{Rh}(\mathrm{I})$-catalyzed addition of an alkenylsilane to an $\mathrm{N}$-sulfonyl aldimine. ${ }^{18}$ ] Therefore, a general enantioselective Rh(I)-catalyzed addition of alkenylboron reagents to imines remains undeveloped.

Herein, we demonstrate that cyclic imines are highly effective substrates for enantioselective $\mathrm{Rh}(\mathrm{I})$-catalyzed additions of potassium alkenyltrifluoroborates, ${ }^{[19,20]}$ providing products in excellent enantioselectivities and generally good yields. The cyclic structure of these imines, where the $\mathrm{C}=\mathrm{N}$ bond is constrained in the Z-geometry, appears to be

[*] Dr. Y. Luo, Dr. H. W. Lam

EaStCHEM, School of Chemistry, University of Edinburgh Joseph Black Building, The King's Buildings, West Mains

Road, Edinburgh EH9 3JJ, United Kingdom

E-mail: h.lam@ed.ac.uk

Homepage: http://homepages.ed.ac.uk/hlam/index.html

Dr. A. J. Carnell

Department of Chemistry, University of Liverpool, Crown Street, Liverpool, L69 7ZD, United Kingdom

[**] We thank the ERC (Starting Grant No. 258580) and the EPSRC (Leadership Fellowship to H. W. L) for support of this work, Dr. Gary S. Nichol (University of Edinburgh) for $X$-ray crystallography, and the EPSRC National Mass Spectrometry Service Centre at the University of Wales, Swansea, for high resolution mass spectra.

Supporting information for this article is available on the WWW under http://www.angewandte.org

A. Diastereoselective $\mathrm{Rh}(\mathrm{l})$-catalyzed addition of alkenylboron reagents to imines<smiles>[R]C([R18])=NS(=O)C([R])[B]</smiles>

B. Enantioselective $\mathrm{Rh}(\mathrm{I})$-catalyzed addition of alkenylboron reagents to imines<smiles>[R16][13CH3]</smiles>

Scheme 1. Rh(I)-catalyzed additions of alkenylborons to imines

important for the success of the reactions.

This study began with attempted alkenylation of acyclic imines 1a-1d with potassium (E)-1-hexenyltrifluoroborate (2 equiv) at $80{ }^{\circ} \mathrm{C}$ in dioxane for $24 \mathrm{~h}$ in the presence of $\mathrm{MeOH}$ ( 5 equiv) and $1.5 \mathrm{~mol} \%$ of the dimeric rhodium complexes derived from chiral diene ligands ${ }^{[21,22]} \mathbf{L 1}^{[15 a]}$ or $\mathbf{L 2}^{[23]}$ (Table 1). Given that imines $\mathbf{1 a}-\mathbf{1 d}$ are highly effective substrates for enantioselective $\mathrm{Rh}(\mathrm{I})$-catalyzed additions of arylboron reagents, ${ }^{[14]}$ and chiral diene $\mathbf{L 1}$ has provided excellent results in these types of reactions, ${ }^{[15 a]}$ we were surprised to learn that imine alkenylation was far from straightforward.

Table 1: Attempted Rh-catalyzed alkenylation of various imines.

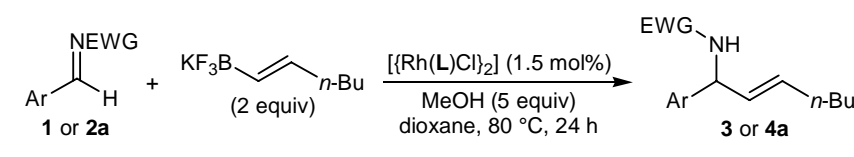

Imines

1a $\quad E W G=T s$ 1b $\quad E W G=N s$ 1c $E W G=P(O) P_{2}$ 1d $\mathrm{EWG}=\mathrm{SO}_{2} \mathrm{NMe}_{2}$
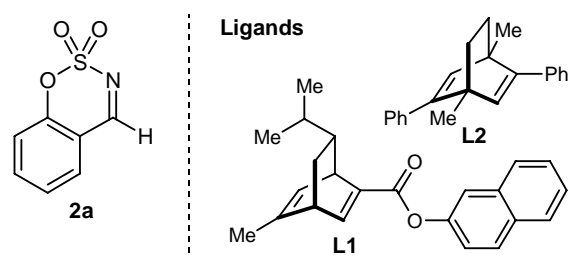

\begin{tabular}{|c|c|c|c|c|c|}
\hline Entry & Imine & Ligand & Product & Yield [\%] ${ }^{[\mathrm{a}]}$ & ee $[\%]^{[b]}$ \\
\hline $\begin{array}{l}1 \\
2\end{array}$ & $1 a$ & $\begin{array}{l}\text { L1 } \\
\text { L2 }\end{array}$ & $3 a$ & $\begin{array}{l}<5 \\
<5\end{array}$ & $\begin{array}{l}n / a \\
n / a\end{array}$ \\
\hline $\begin{array}{l}3 \\
4\end{array}$ & $1 b$ & $\begin{array}{l}\text { L1 } \\
\text { L2 }\end{array}$ & $3 b$ & $\begin{array}{l}11 \\
80\end{array}$ & $\begin{array}{l}23 \\
7\end{array}$ \\
\hline $\begin{array}{l}5 \\
6\end{array}$ & $1 c$ & $\begin{array}{l}\text { L1 } \\
\text { L2 }\end{array}$ & $3 c$ & $\begin{array}{l}<5^{[\mathrm{c}]} \\
<5^{[\mathrm{c}]}\end{array}$ & $\begin{array}{l}\text { n/a } \\
\text { n/a }\end{array}$ \\
\hline $\begin{array}{l}7 \\
8\end{array}$ & $1 d$ & $\begin{array}{l}\text { L1 } \\
\text { L2 }\end{array}$ & $3 d$ & $\begin{array}{l}45 \\
55\end{array}$ & $\begin{array}{l}43 \\
55\end{array}$ \\
\hline $\begin{array}{l}9 \\
10\end{array}$ & $2 a$ & $\begin{array}{l}\text { L1 } \\
\text { L2 }\end{array}$ & $4 a$ & $\begin{array}{l}76 \\
>95\end{array}$ & $\begin{array}{l}96 \\
98\end{array}$ \\
\hline
\end{tabular}

[a] NMR yields calculated using nitromethane as an internal standard. [b] Determined by HPLC analysis on a chiral stationary phase. [c] Significant decomposition of $\mathbf{1 c}$ was observed. 
Tosylimine 1a and diphenylphosphinoylimine 1c were not viable substrates, and no alkenylation was observed using $\mathbf{L 1}$ (entries 1 and 5). In these reactions, imine 1a remained largely intact, but imine 1c underwent significant decomposition. While appreciable alkenylation was observed using $\mathbf{L 1}$ with both nosylimine $\mathbf{1 b}$ and $N, N$ dimethylsulfamylimine 1d,the enantiomeric excesses of the corresponding products were low (entries 3 and 7). Similar results were obtained using $\mathbf{L} \mathbf{2}$ as the ligand (entries 2, 4, 6, and 8 ), with the exception that alkenylation was significant with nosylimine $\mathbf{1 b}$ (entry 4 ).

The results of entries 1-8 clearly highlight the difficulties of these alkenylation reactions compared with the corresponding arylations. ${ }^{[13-15]}$ The mostly poor conversions into the desired products may be explained by the lower stability of alkenylrhodium species compared with arylrhodium species, which renders protodeboronation or other decomposition pathways highly competitive with imine addition. ${ }^{[24]}$ However, it is more difficult to rationalize the low enantioselectivities obtained when alkenylation was successful (Table 1, entries 3, 4, 7, and 8). One factor to consider in all catalytic asymmetric additions to imines is the possibility of $E / Z$ isomerization of the imine during the reaction, which usually has a negative impact upon stereoselectivity. ${ }^{[7 a]}$ Although this issue does not appear to be problematic for $\mathrm{Rh}(\mathrm{I})$-catalyzed imine arylation, ${ }^{[13-15]}$ we surmised that it could be important in imine alkenylation.

To test this theory, the alkenylation of benzoxathiazine2,2-dioxide 2a, a cyclic imine where $E / Z$ isomerization is precluded, was examined. Surprisingly, to our knowledge, benzoxathiazine-2,2-dioxides have been virtually unexplored as electrophiles for carbon nucleophiles. ${ }^{[25,26]} \mathrm{We}$ were therefore delighted to observe that under conditions identical to those employed for imines 1a-1d, imine 2a provided the alkenylation product 4a in high conversions and enantioselectivities (Table 1, entries 9 and 10), with ligand L2 giving the best results (entry 10). ${ }^{[27]}$

Under the optimized conditions, imine 2a smoothly

Table 2: Alkenylation of benzoxathiazine-2,2-dioxide $\mathbf{2 a}$.
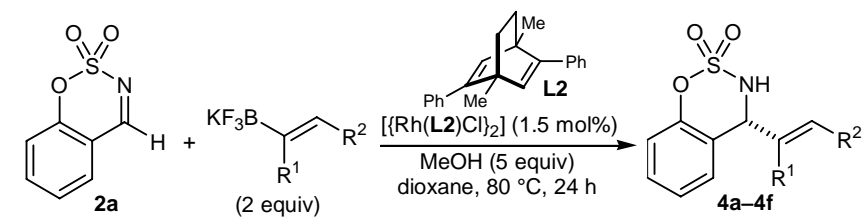

\begin{tabular}{|c|c|c|c|c|}
\hline Entry & Trifluoroborate & Product & Yield $[\%]]^{\mathrm{a}]}$ & ee $[\%]^{[b]}$ \\
\hline 1 & $n-B u$ & $4 a$ & 90 & 98 \\
\hline 2 & $\mathrm{KF}_{3} \mathrm{~B}$ & $4 b$ & 75 & 98 \\
\hline 3 & $\mathrm{KF}_{3} \mathrm{~B}$ & 4c & 79 & 97 \\
\hline 4 & $\mathrm{KF}_{3} \mathrm{~B}$ & $4 d$ & 94 & 99 \\
\hline 5 & $\mathrm{KF}_{3} \mathrm{~B}$ & $4 e$ & 88 & 95 \\
\hline 6 & & $4 f$ & 94 & 94 \\
\hline
\end{tabular}

[a] Isolated yields. [b] Determined by HPLC analysis on a chiral stationary phase. $\mathrm{PMP}=$ para-methoxyphenyl. reacted with various alkenyltrifluoroborates ${ }^{[28]}$ containing alkyl (Table 2, entries 1, 3, and 4) or aryl (entry 5) substituents at the $\beta$-carbon to provide alkenylation products in good yields and high enantioselectivities (95-99\% ee). In addition, vinylation was successful (entry 2), and substitution at the $\alpha$-carbon of the alkenyltrifluoroborate was tolerated (entry 6). Interestingly, conducting the experiments in entries 2 and 3 with the corresponding alkenyl MIDA boronates in place of the alkenyltrifluoroborates under conditions described by Brak and Ellman ${ }^{[17 \mathrm{~b}]}$ provided only $<20 \%$ conversion into $\mathbf{4 b}$ and $\mathbf{4 c}$, respectively.

Table 3 presents the alkenylation of more highly substituted benzoxathiazine-2,2-dioxides. Imines containing a range of arene substituents (including methyl, methoxy, chloro, bromo, and fluoro) at various positions were competent substrates, providing alkenylation products in $\geq 81 \%$ yield and $\geq 94 \%$ ee (products $5 \mathbf{a}-5 \mathbf{i}$ ). However, the reaction of potassium vinyltrifluoroborate with a benzoxathiazine-2,2-dioxide containing the electron-donating dioxole group provided $5 \mathbf{j}$ in only $50 \%$ yield, though in $97 \%$ ee. Presumably, the modest yield observed here is due to the greater propensity of potassium vinyltrifluoroborate to undergo protodeboronation compared with its more sterically

Table 3: Alkenylation of various benzoxathiazine-2,2-dioxides. ${ }^{\text {[a] }}$

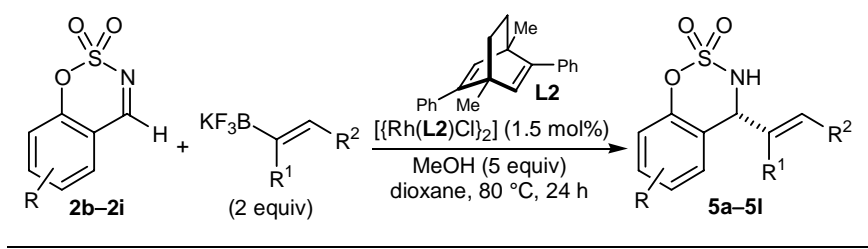

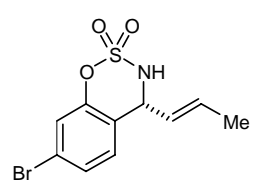

5a $92 \%, 98 \%$ ee

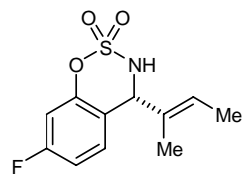

5d $85 \%, 95 \%$ ee<smiles>O=S1(=O)N[C@H](C=CC2CCCCC2)c2cc(Cl)ccc2O1</smiles>

5g $86 \%, 97 \%$ ee

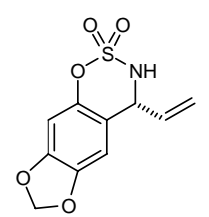

5j $50 \%, 97 \%$ ee

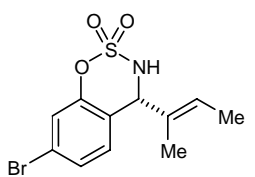

5b $88 \%, 94 \%$ ee

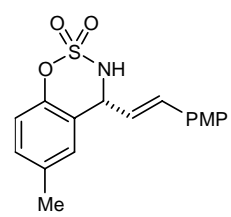

5e $81 \%, 96 \%$ ee<smiles>O=S1(=O)N[C@H](/C=C/c2ccccc2)c2cc(Cl)ccc2O1</smiles>

5h $81 \%, 97 \%$ ee

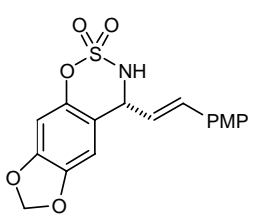

5k $93 \%, 94 \%$ ee

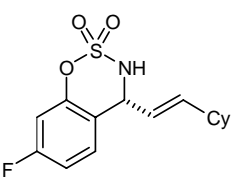

5c $83 \%,>99 \%$ ee

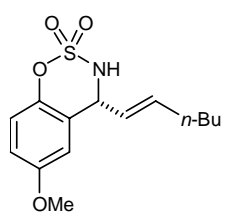

5f $86 \%, 97 \%$ ee

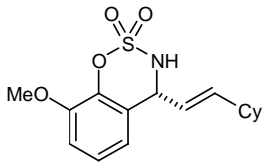

5i $93 \%, 98 \%$ ee

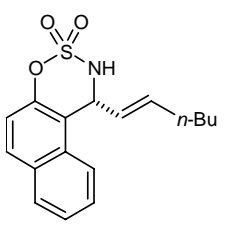

5I $55 \%, 96 \%$ ee [a] Cited yields are of isolated material. Enantiomeric excesses were determined by HPLC analysis on a chiral stationary phase. PMP = para-methoxyphenyl. 
hindered counterparts, a problem that is compounded by the lower electrophilicity of this imine. As expected, a more highly substituted alkenyltrifluoroborate provided better results, with $5 \mathbf{k}$ being formed in $93 \%$ yield and $94 \%$ ee. Finally, the benzoxathiazine-2,2-dioxide derived from 2hydroxy-1-naphthaldehyde was also a suitable substrate, though the steric hindrance associated with this imine led to the product $5 \mathrm{l}$ being formed in a modest $55 \%$ yield.

Cyclic $N$-sulfonyl ketimine $\mathbf{6}$ was also a viable substrate, providing sultam 7 in $68 \%$ and $90 \%$ ee [Eq. (1)]. ${ }^{[29]}$ This result further confirms the beneficial effect of a cyclic imine structure, and demonstrates that the high efficiency of these reactions is not confined to benzoxathiazine-2,2-dioxides.
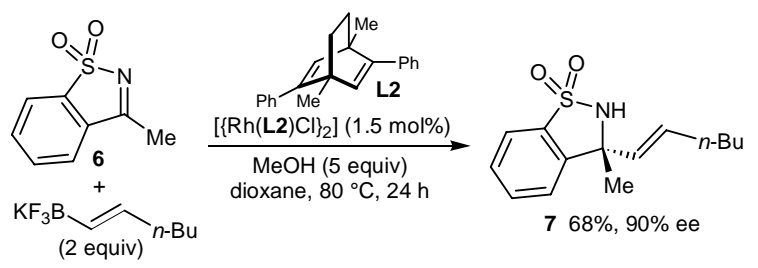

The sense of enantioinduction of these reactions ${ }^{[27]}$ is consistent with the stereochemical model proposed for the 1,4-arylation of cyclic enones. ${ }^{[21 \mathrm{a}]}$ Following this model, binding of the imine to the chiral diene-ligated alkenylrhodium species is suggested to occur in a manner that minimizes unfavorable nonbonding interactions between the imine activating group and one phenyl substituent of the ligand (Figure 1). Carborhodation from the re-face of the imine then occurs to eventually provide the product. ${ }^{[30,31]}$

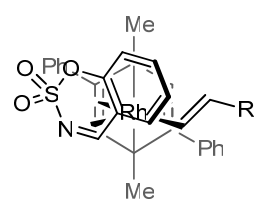

Disfavored

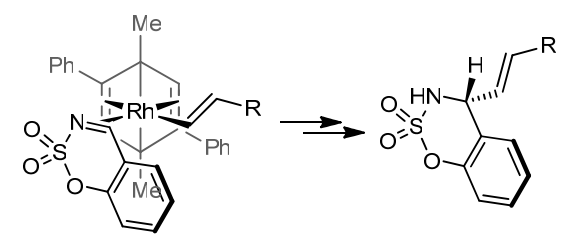

Favored
Figure 1. Possible stereochemical model for the formation of 4.
Scheme 2 illustrates the utility of the alkenylation products. Aryl sulfamates have recently been shown to be highly effective in a range of nickel-catalyzed cross-coupling reactions. ${ }^{[32,33,34]}$ For example, Wehn and Du Bois have described Kumada couplings of cyclic aryl sulfamates, ${ }^{[32 b]}$ and Garg and co-workers have developed Suzuki-Miyaura reactions of their acyclic counterparts. ${ }^{[33 a, b]}$ It was therefore of interest to ascertain whether nickel-catalyzed SuzukiMiyaura reactions would be successful with cyclic aryl sulfamates derived from the alkenylation products of this study. To this end, 4a was converted into cyclic sulfamate $\mathbf{8}$ by alkene hydrogenation followed by $N$-methylation. Gratifyingly, application of Garg's conditions ${ }^{[33 a, b]}$ for Suzuki-Miyaura coupling of 8 with $\mathrm{PhB}(\mathrm{OH})_{2}$ smoothly delivered the biaryl compound $\mathbf{9}$ in $72 \%$ yield after acidmediated cleavage of the sulfamic acid intermediate.

Next, a hydroboration/oxidation sequence of $\mathbf{4 b}$ gave alcohol 10 in $91 \%$ yield. Treatment of 8 with $\mathrm{LiAlH}_{4}$ at reflux ${ }^{[35]}$ followed by $\mathrm{Boc}_{2} \mathrm{O}$ provided carbamate 11, which was then converted into chroman-4-amine 12 via a Mitsunobu cyclization. Chroman-4-amines appear as core scaffolds in several drug discovery programs, for example in the human bradykinin B1 receptor antagonist $13 .^{[36]}$

Finally, $N$-allylation of $\mathbf{4 b}$ gave diene 14 which underwent efficient ring-closing metathesis using the $2^{\text {nd }}$ generation Grubbs catalyst ${ }^{[37]}$ to give dihydropyrrole 15. Dihydroxylation of $\mathbf{1 5}$ from the least hindered face followed by acetonide protection of the resulting diol provided 16, which was then transformed into the biaryl-containing dihydroxylated pyrrolidine 17 in $84 \%$ yield by nickelcatalyzed Kumada coupling with $\mathrm{PhMgBr}$ and acidic workup according to the method of Wehn and Du Bois. ${ }^{[32 b]}$ 2-Aryl dihydroxylated pyrrolidines similar to $\mathbf{1 7}$ are of interest as potential glycosidase inhibitors. ${ }^{[38]}$

In conclusion, the first enantioselective Rh-catalyzed additions of alkenylboron compounds to cyclic imines have been described. The cyclic structure of these imines, where the $\mathrm{C}=\mathrm{N}$ bond is constrained in the Z-geometry, appears to be important, allowing alkenylation to proceed in generally good

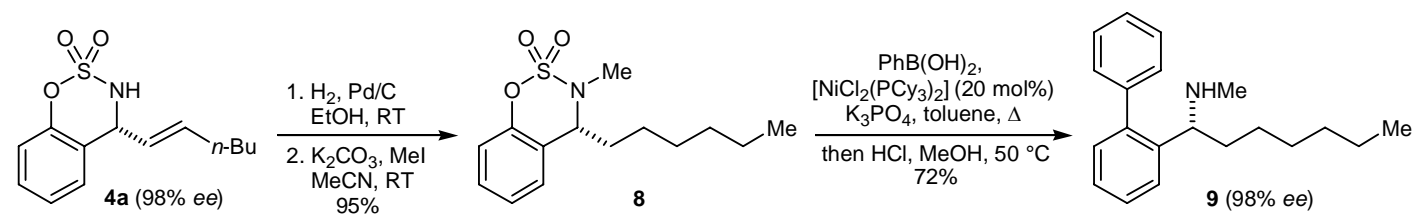
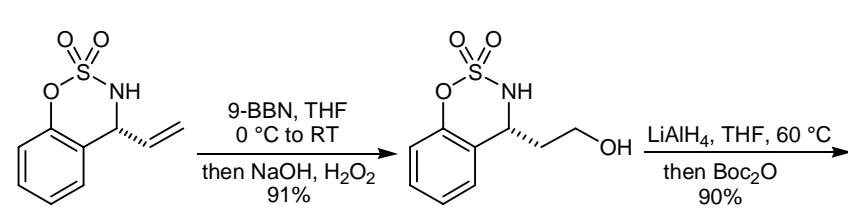

$\mathbf{4 b}(98 \%$ ee)

10 $90 \%$

allyl bromide, $\mathrm{K}_{2} \mathrm{CO}_{3}, \mathrm{MeCN}, \mathrm{RT}$ $>95 \%$

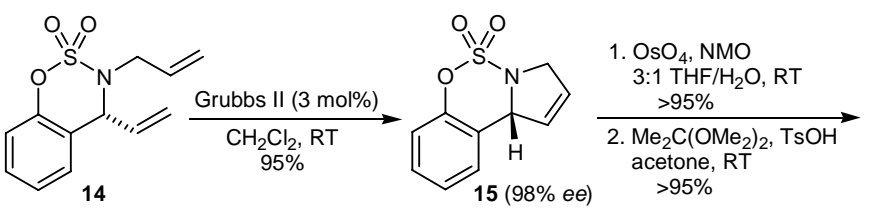

1. $\mathrm{OsO}_{4}, \mathrm{NMO}$
3:1 $\mathrm{THF} / \mathrm{H}_{2} \mathrm{O}, \mathrm{RT}$
$>95 \%$
$\stackrel{\text { 2. } \mathrm{Me}_{2} \mathrm{C}\left(\mathrm{OMe}_{2}\right)_{2}, \mathrm{TsOH}}{\text { acetone }, \mathrm{RT}}$ $>95 \%$

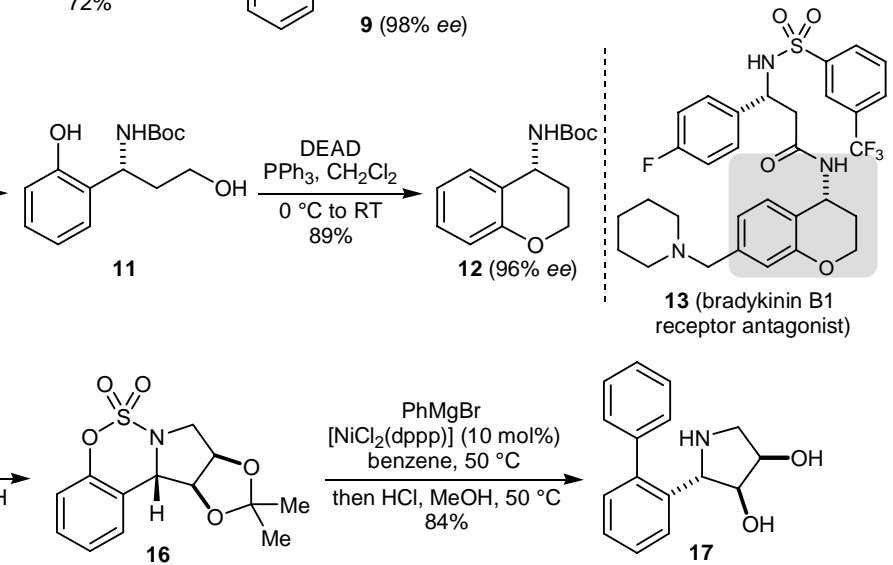

Scheme 2. Further transformations of alkenylation products 
yields and high enantioselectivities ( $\geq 94 \%$ ee). Moreover, products containing aryl sulfamates may be exploited in subsequent reactions, including nickel-catalyzed crosscouplings, to generate further useful compounds.

Received: ((will be filled in by the editorial staff))

Published online on ((will be filled in by the editorial staff))

Keywords: alkenyltrifluoroborate $\cdot$ asymmetric catalysis ·

enantioselectivity $\cdot$ imine $\cdot$ rhodium

[1] For seminal references, see: a) B. M. Trost, D. L. Van Vranken, C. Bingel, J. Am. Chem. Soc. 1992, 114, 9327-9343; b) T. Ohmura, J. F. Hartwig, J. Am. Chem. Soc. 2002, 124, 15164-15165.

[2] For reviews, see: a) B. M. Trost, D. L. Van Vranken, Chem. Rev. 1996 96, 395-422; b) B. M. Trost, M. L. Crawley, Chem. Rev. 2003, 103 , 2921-2943; c) G. Helmchen, A. Dahnz, P. Dubon, M. Schelwies, R. Weihofen, Chem. Commun. 2007, 675-691; d) Z. Lu, S. Ma, Angew. Chem. Int. Ed. 2008, 47, 258-297; Angew. Chem. 2008, 120, 264-303; e) J. F. Hartwig, L. M. Stanley, Acc. Chem. Res. 2010, 43, 1461-1475

[3] For selected recent examples, see: a) L. M. Stanley, J. F. Hartwig, Angew. Chem. Int. Ed. 2009, 48, 7841-7844; Angew. Chem. 2009, 121 7981-7984; b) M. J. Pouy, L. M. Stanley, J. F. Hartwig, J. Am. Chem. Soc. 2009, 131, 11312-11313; c) M. Gaertner, M. Jaekel, M. Achatz, C. Sonnenschein, O. Tverskoy, G. Helmchen, Org. Lett. 2011, 13, 2810-2813; d) K.-Y. Ye, H. He, W.-B. Liu, L.-X. Dai, G. Helmchen, S.-L. You, J. Am. Chem. Soc. 2011, 133, 19006-19014; e) M. Lafrance, M. Roggen, E. M. Carreira, Angew. Chem. Int. Ed. 2012, 51 , 3470-3473; Angew. Chem. 2012, 124, 3527-3530.

[4] For a seminal reference: M. Calter, T. K. Hollis, L. E. Overman, J. Ziller, G. G. Zipp, J. Org. Chem. 1997, 62, 1449-1456.

[5] For a review, see: H. Nomura, C. J. Richards, Chem. Asian. J. 2010, 5, 1726-1740.

[6] For selected recent examples, see: a) D. F. Fischer, A. Barakat, Z.-q. Xin, M. E. Weiss, R. Peters, Chem. Eur. J. 2009, 15, 8722-8741; b) R. Peters, Z.-q. Xin, F. Maier, Chem. Asian. J. 2010, 5, 1770-1774.

[7] For recent reviews covering catalytic asymmetric additions of nonstabilized carbon nucleophiles to imines, see: a) S. Kobayashi, Y. Mori, J. S. Fossey, M. M. Salter, Chem. Rev. 2011, 111, 2626-2704; b) A. B. Charette, Chiral Amine Synthesis 2010, 1-49.

[8] Enantioselective metal-catalyzed reductive coupling of alkynes and imines: a) S. J. Patel, T. F. Jamison, Angew. Chem. Int. Ed. 2004, 43 , 3941-3944; Angew. Chem. 2004, 116, 4031-4034; b) E. Skucas, J. R. Kong, M. J. Krische, J. Am. Chem. Soc. 2007, 129, 7242-7243; c) M.Y. Ngai, A. Barchuk, M. J. Krische, J. Am. Chem. Soc. 2007, 129, 12644-12645; d) C.-Y. Zhou, S.-F. Zhu, L.-X. Wang, Q.-L. Zhou, J. Am. Chem. Soc. 2010, 132, 10955-10957.

[9] Catalytic enantioselective Petasis reactions: a) Y. Yamaoka, H. Miyabe, Y. Takemoto, J. Am. Chem. Soc. 2007, 129, 6686-6687; b) S. Lou, S. E. Schaus, J. Am. Chem. Soc. 2008, 130, 6922-6923; c) T. Inokuma, Y. Suzuki, T. Sakaeda, Y. Takemoto, Chem. Asian. J. 2011, 6, 2902-2906; d) T. Kodama, P. N. Moquist, S. E. Schaus, Org. Lett. 2011, 13, 6316-6319.

[10] Enantioselective additions of alkenylmetal reagents to dihydroisoquinoline derivatives: a) S. Wang, C. T. Seto, Org. Lett. 2006, 8, 3979-3982; b) A. Saito, K. Iimura, M. Hayashi, Y. Hanzawa, Tetrahedron Lett. 2009, 50, 587-589.

[11] Enantioselective chiral Brønsted acid-catalyzed additions of $\alpha, \beta$ unsaturated hydrazones to imines: T. Hashimoto, H. Kimura, K Maruoka, Angew. Chem. Int. Ed. 2010, 49, 6844-6847; Angew. Chem. 2010, 122, 6996-6999.

[12] For selected examples of catalytic enantioselective aza-MoritaBaylis-Hillman reactions, see: a) M. Shi, Y. M. Xu, Angew. Chem. Int. Ed. 2002, 41, 4507-4510; Angew. Chem. 2002, 114, 4689-4692; b) K. Matsui, S. Takizawa, H. Sasai, J. Am. Chem. Soc. 2005, 127, 36803681; c) M. Shi, L. H. Chen, C. Q. Li, J. Am. Chem. Soc. 2005, 127, 3790-3800; d) I. T. Raheem, E. N. Jacobsen, Adv. Synth. Catal. 2005, 347, 1701-1708; e) N. Abermil, G. Masson, J. Zhu, J. Am. Chem. Soc.
2008, 130, 12596-12597; f) T. Yukawa, B. Seelig, Y. J. Xu, H. Morimoto, S. Matsunaga, A. Berkessel, M. Shibasaki, J. Am. Chem. Soc. 2010, 132, 11988-11992.

[13] For seminal references, see: a) M. Kuriyama, T. Soeta, X. Y. Hao, O. Chen, K. Tomioka, J. Am. Chem. Soc. 2004, 126, 8128-8129; b) N. Tokunaga, Y. Otomaru, K. Okamoto, K. Ueyama, R. Shintani, T. Hayashi, J. Am. Chem. Soc. 2004, 126, 13584-13585.

[14] For a review, see: C. S. Marques, A. J. Burke, ChemCatChem 2011, 3, 635-645.

[15] For selected recent examples, see: a) K. Okamoto, T. Hayashi, V. H. Rawal, Chem. Commun. 2009, 4815-4817; b) R. Shintani, M. Takeda, T. Tsuji, T. Hayashi, J. Am. Chem. Soc. 2010, 132, 13168-13169; c) R. Shintani, M. Takeda, Y.-T. Soh, T. Ito, T. Hayashi, Org. Lett. 2011, 13, 2977-2979; d) R. Shintani, R. Narui, Y. Tsutsumi, S. Hayashi, T. Hayashi, Chem. Commun. 2011, 6123-6125; e) X. Hao, Q. Chen, K.-i. Yamada, Y. Yamamoto, K. Tomioka, Tetrahedron 2011, 67, 64696473; f) Z. Cui, H.-J. Yu, R.-F. Yang, W.-Y. Gao, C.-G. Feng, G.-Q. Lin, J. Am. Chem. Soc. 2011, 133, 12394-12397; g) T. Nishimura, A. Noishiki, G. Chit Tsui, T. Hayashi, J. Am. Chem. Soc. 2012, 134, 5056-5059.

[16] For early racemic work involving alkenyltin or alkenylzirconium reagents, see: a) S. Oi, M. Moro, H. Fukuhara, T. Kawanishi, Y. Inoue, Tetrahedron Lett. 1999, 40, 9259-9262; b) A. Kakuuchi, T. Taguchi, Y. Hanzawa, Tetrahedron Lett. 2003, 44, 923-926.

[17] a) K. Brak, J. A. Ellman, J. Am. Chem. Soc. 2009, 131, 3850-3851; b) K. Brak, J. A. Ellman, J. Org. Chem. 2010, 75, 3147-3150; c) K. Brak, J. A. Ellman, Org. Lett. 2010, 12, 2004-2007.

[18] Y. Nakao, M. Takeda, J. Chen, T. Hiyama, Y. Ichikawa, R. Shintani, T. Hayashi, Chem. Lett. 2008, 37, 290-291.

[19] For reviews on organotrifluoroborates, see: a) G. A. Molander, D. L. Sandrock, Curr. Opin. Drug Discovery Dev. 2009, 12, 811-823; b) S. Darses, J.-P. Genet, Chem. Rev. 2008, 108, 288-325.

[20] For related metal-catalyzed additions of potassium allyltrifluoroborates to imines, see: a) N. Solin, O. A. Wallner, K. J. Szabo, Org. Lett. 2005, 7, 689-691; b) J. Aydin, K. S. Kumar, M. J. Sayah, O. A. Wallner, K. Szabó, J. Org. Chem. 2007, 72, 4689-4697; c) T. R. Ramadhar, R. A. Batey, Synthesis 2011, 1321-1346.

[21] For seminal references of chiral dienes in asymmetric catalysis, see: a) T. Hayashi, K. Ueyama, N. Tokunaga, K. Yoshida, J. Am. Chem. Soc. 2003, 125, 11508-11509; b) C. Fischer, C. Defieber, T. Suzuki, E. M. Carreira, J. Am. Chem. Soc. 2004, 126, 1628-1629.

[22] For reviews of chiral diene ligands, see: a) C.-G. Feng, M.-H. Xu, G.Q. Lin, Synlett 2011, 1345-1356; b) R. Shintani, T. Hayashi, Aldrichimica. Acta 2009, 42, 31-38; c) J. B. Johnson, T. Rovis, Angew. Chem. Int. Ed. 2008, 47, 840-871; Angew. Chem. 2008, 120, 852-884; d) C. Defieber, H. Grutzmacher, E. M. Carreira, Angew. Chem. Int. Ed. 2008, 47, 4482-4502; Angew. Chem. 2008, 120, 45584579.

[23] Y. Luo, A. J. Carnell, Angew. Chem. Int. Ed. 2010, 49, 2750-2754; Angew. Chem. 2010, 122, 2810-2814.

[24] For similar observations, see ref. 17b and G. Pattison, G. Piraux, H. W. Lam, J. Am. Chem. Soc. 2010, 132, 14373-14375.

[25] a) M. Tripathi, D. N. Dhar, J. Heterocycl. Chem. 1988, 25, 11911192; b) B.-H. Zhu, J.-C. Zheng, C.-B. Yu, X.-L. Sun, Y.-G. Zhou, Q. Shen, Y. Tang, Org. Lett. 2010, 12, 504-507.

[26] During the submission of this manuscript, the group of Hayashi and Nishimura reported the enantioselective rhodium-catalyzed arylation of cyclic $N$-sulfonyl ketimines. See: ref. $15 \mathrm{~g}$.

[27] The absolute configurations of the products obtained herein were assigned by analogy with that of $\mathbf{4 f}$, which was determined by X-ray crystallography. See Supporting Information for details. CCDC 870995 contains the supplementary crystallographic data for this paper. These data can be obtained free of charge from The Cambridge Crystallographic Data Centre via www.ccdc.cam.ac.uk/data request/cif.

[28] While use of alkenylboronic acids or alkenyl pinacolboronic esters was successful in certain cases, potassium alkenyltrifluoroborates are the reagents of choice in these reactions. See Supporting Information for full details. 
[29] For another application of these cyclic $N$-sulfonyl ketimines in catalysis, see: M. Rommel, T. Fukuzumi, J. W. Bode, J. Am. Chem. Soc. 2008, 130, 17266-17267.

[30] Although this model successfully explains the stereochemical outcome, it is empirical in nature, and recent DFT calculations on the origin of enantioselectivity in $\mathrm{Rh}$ /chiral diene-catalyzed 1,4-arylation of cyclohexenone suggest the situation may actually be more complex. See: a) E. A. B. Kantchev, Chem. Commun. 2011, 10969-10971; b) S. Gosiewska, J. A. Raskatov, R. Shintani, T. Hayashi, J. M. Brown, Chem. Eur. J. 2012, 18, 80-84; c) Y. Luo, N. G. Berry, A. J. Carnell, Chem. Commun. 2012, 48, 3279-3281.

[31] For a proposed catalytic cycle for these reactions, see Supporting Information.

[32] Kumada couplings: a) T. K. Macklin, V. Snieckus, Org. Lett. 2005, 7, 2519-2522; b) P. M. Wehn, J. Du Bois, Org. Lett. 2005, 7, 4685-4688.

[33] Suzuki-Miyaura couplings: a) K. W. Quasdorf, M. Riener, K. V. Petrova, N. K. Garg, J. Am. Chem. Soc. 2009, 131, 17748-17749; b) K W. Quasdorf, A. Antoft-Finch, P. Liu, A. L. Silberstein, A. Komaromi, T. Blackburn, S. D. Ramgren, K. N. Houk, V. Snieckus, N. K. Garg, J.
Am. Chem. Soc. 2011, 133, 6352-6363; c) M. Baghbanzadeh, C. Pilger, C. O. Kappe, J. Org. Chem. 2011, 76, 1507-1510.

[34] Aminations: S. D. Ramgren, A. L. Silberstein, Y. Yang, N. K. Garg, Angew. Chem. Int. Ed. 2011, 50, 2171-2173; Angew. Chem. 2011, 123, 2219-2221.

[35] Y.-Q. Wang, C.-B. Yu, D.-W. Wang, X.-B. Wang, Y.-G. Zhou, Org. Lett. 2008, 10, 2071-2074.

[36] K. Biswas, A. Li, J. J. Chen, D. C. D'Amico, C. Fotsch, N. Han, J. Human, Q. Liu, M. H. Norman, B. Riahi, C. Yuan, H. Suzuki, D. A. Mareska, J. Zhan, D. E. Clarke, A. Toro, R. D. Groneberg, L. E. Burgess, D. Lester-Zeiner, G. Biddlecome, B. H. Manning, L. Arik, H. Dong, M. Huang, A. Kamassah, R. Loeloff, H. Sun, F.-Y. Hsieh, G. Kumar, G. Y. Ng, R. W. Hungate, B. C. Askew, E. Johnson, J. Med. Chem. 2007, 50, 2200-2212.

[37] M. Scholl, S. Ding, C. W. Lee, R. H. Grubbs, Org. Lett. 1999, 1, 953 956.

[38] T. M. Chapman, S. Courtney, P. Hay, B. G. Davis, Chem. Eur. J. 2003, 9, 3397-3414. 


\section{Asymmetric Catalysis}

Y. Luo, A. J. Carnell, H. W. Lam* Page - Page

Enantioselective Rhodium-Catalyzed Addition of Potassium

Alkenyltrifluoroborates to Cyclic Imines<smiles>[R]C1=NS(=O)(=O)Cc2[R]#cccc21</smiles>

$\underbrace{\mathrm{KF}_{3} \mathrm{~B}}_{\mathrm{R}^{2}} \mathrm{R}^{3}$ $\mathrm{Ph}$ (cat.) Rh (cat.)

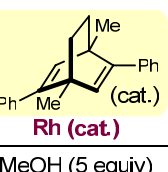
$\mathrm{MeOH}(5$ equiv)
dioxane, $80^{\circ} \mathrm{C}$ 19 examples<smiles>[R]C=C([R])[C@H]1NS(=O)(=O)Oc2[R]#cccc21</smiles>

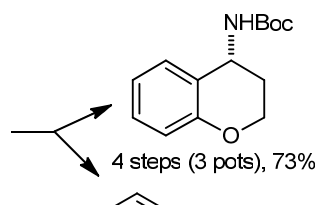

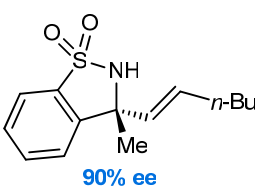

Fixed: Cyclic imines, where the $\mathrm{C}=\mathrm{N}$ bond is constrained in the Z-geometry, have been identified as highly effective substrates for enantioselective rhodiumcatalyzed additions of potassium alkenyltrifluoroborates. Not only is the alkene in the products a useful functional handle for subsequent manipulations, products containing aryl sulfamates may be employed in nickelcatalyzed Suzuki-Miyaura and Kumada couplings to generate further compounds of interest. 